Magdalena Jankowska*

\title{
PODMIOTOWOŚĆ I SAMODZIELNOŚĆ ZWIAZZKU MIĘDZYGMINNEGO W ŚWIETLE DECENTRALIZACJI WŁADZY PUBLICZNEJ
}

\section{Decentralizacja władzy publicznej w polskim porządku prawnym}

W myśl art. 15 ust. 1 Konstytucji RP „ustrój terytorialny Rzeczypospolitej Polskiej zapewnia decentralizację władzy publicznej”. Decentralizacja stanowi określony typ organizacji i funkcjonowania państwa oraz społeczeństwa, w szczególności dotyczący administracji publicznej. Polega na przekazywaniu zadań publicznych ${ }^{1}$ do wykonywania przez podmioty administracji publicznej usytuowane wyżej w systemie organizacyjnym państwa - podmiotom usytuowanym ni$\dot{z} \mathrm{ej}^{2}$. Otrzymane do wykonania zadania jednostki organizacyjne administracji realizują w sposób samodzielny, niezależny i wolny od wytycznych, także wtedy, gdy pozostają pod nadzorem państwowym³ ${ }^{3}$.

Magdalena Jankowska - Uniwersytet Mikołaja Kopernika w Toruniu.

1 B. Banaszak wskazuje, że przekazywanie uprawnień jednostek władzy publicznej wyższego szczebla jednostkom niższego oznacza także przekazywanie środków (w tym finansowych) będących w dyspozycji jednostek władzy publicznej wyższego szczebla dla wykonywania zadań jednostkom niższego szczebla - B. Banaszak, Konstytucja Rzeczypospolitej Polskiej. Komentarz, Warszawa 2012, s. 133.

2 K. Łokucijewski, Decentralizacja, centralizacja [w:] Leksykon prawa administracyjnego. 100 podstawowych pojęć, red. E. Bojanowski, K. Żukowski, Warszawa 2009, s. 42.

${ }^{3}$ S. Fundowicz, Decentralizacja władzy publicznej [w:] Encyklopedia samorządu terytorialnego, red. K. Miaskowska-Daszkiewicz, B. Szmulik, Warszawa 2010, s. 173. 
Samodzielność i niezależność w działaniu podmiotów zdecentralizowanych związana jest nierozerwalnie z korzystaniem $\mathrm{z}$ własnych kompetencji oraz wykonywaniem zadań we własnym imieniu i na własną odpowiedzialność - w sytuacji braku hierarchicznego podporządkowania ${ }^{4}$.

Co istotne, organy zdecentralizowane nigdy nie dysponują pełnią wszelkich kompetencji, gdyż część z nich musi być zarezerwowana dla organów ustawodawczych, a część dla organów administracji rządowej ${ }^{5}$. Dodatkowo decentralizacja nie oznacza zupełnego uniezależnienia podmiotów zdecentralizowanych od państwa. Samodzielność funkcjonowania organów w zdecentralizowanym systemie władzy publicznej nie ma charakteru kategorycznego i absolutnego, gdyż jej granice wyznaczają środki nadzoru, które mogą być wcielane w życie jedynie w przypadkach wskazanych w ustawie ${ }^{6}$.

W polskim porządku prawnym decentralizacja władzy publicznej może przybierać różne formy, takie jak zakłady administracyjne, samorządy zawodowe czy samorządy gospodarcze. Najistotniejszym jednak jej przejawem jest istnienie samorządu terytorialnego, czyli wyodrębnionego w strukturze państwa, powstałego z mocy prawa związku lokalnego społeczeństwa, powoływanego do samodzielnego wykonywania administracji publicznej i wyposażonego w materialne środki umożliwiające realizację tychże zadań ${ }^{7}$ Samorząd terytorialny uważa się za „jedną z postaci władzy wykonawczej, funkcjonującej w ramach władztwa zdecentralizowanego - niepodporządkowanego hierarchicznie organowi administracji

${ }^{4}$ K. Łokucijewski, Decentralizacja... [w:] Leksykon..., red. E. Bojanowski, K. Żukowski, s. 42.

${ }^{5}$ Same względy efektywności przemawiają za tym, aby pozostawić pewne kategorie spraw (np. z zakresu obrony narodowej czy bezpieczeństwa publicznego) administracji scentralizowanej - K. Łokucijewski, Decentralizacja... [w:] Leksykon..., red. E. Bojanowski, K. Żukowski, s. 42-43.

${ }^{6}$ D. Dąbek, J. Zimmermann, Decentralizacja poprzez samorzad terytorialny w ustawodawstwie i orzecznictwie pokonstytucyjnym [w:] Samorzad terytorialny. Zasady ustrojowe i praktyka, red. P. Sarnecki, Warszawa 2005, s. 7.

7 E. Ochendowski, Prawo administracyjne. Część ogólna, Toruń 2006, s. 331. 
rządowej"8. Jak podkreśla Trybunał Konstytucyjny w postanowieniu z 30.11.1999 r., ,istotą samorządu terytorialnego jest to, że pewne dziedziny spraw, wydzielonych z zakresu władzy państwa, powierza się wspólnotom do samodzielnego rozwiązywania. Zadania, które przypadają organom samorządu stanowią część zadań administracji publicznej i są realizowane przez organy samorządowe podporządkowane wspólnocie i realizujące jej interesy"9. Jednostki samorządu terytorialnego posiadają osobowość prawną typu publicznoprawnego i osobowość cywilnoprawną, dzięki czemu mogą wykonywać zadania publiczne i realizować kompetencje we własnym imieniu i na własną odpowiedzialność, korzystając w tym zakresie z ochrony sądowej ${ }^{10}$. Jednocześnie mogą dysponować środkami przekazanymi lub pozyskanymi na rzecz danej działalności ${ }^{11}$. Jednostki samorządu terytorialnego, praktykując misję zdecentralizowanej władzy publicznej, korzystają z daleko posuniętej samodzielności. Jednym z wielu jej wyznaczników jest możliwość zrzeszania, za które należy uważać każdą instytucjonalną formę współpracy jednostek samorządu terytorialnego ${ }^{12}$.

\section{Charakter prawny związku międzygminnego}

Tak jak istota samorządności, tak i współdziałanie jednostek samorządu terytorialnego jako organów władzy publicznej stanowi fundament współczesnej demokratycznej Polski ${ }^{13}$. Jak zauważa B. Banaszak, sposobność tworzenia zrzeszeń jednostek samorządu terytorialnego $\mathrm{z}$ jednej strony stymuluje procesy decentralizacyjne, z drugiej zaś usprawnia działania samorządu i jego organów ${ }^{14}$. Ustawodawca konstytucyjny nie określa zasad korzystania z prawa zrzeszania się przez

${ }^{8}$ J. Stępień, Samorząd w ustawie zasadniczej, ST 1994/11, s. 41.

9 Postanowienie TK z 30.11.1999 r., Ts 104/99, OTK 2000/1, poz. 21.

${ }^{10}$ Wyrok WSA w Lublinie z 11.05.2010 r., III SA/Lu 26/10, LEX nr 689173.

${ }^{11}$ G. Giejłaszewska, Wpływ decentralizacji na organizacje terytorialna państwa [w:] Decentralizacja wspótczesnego państwa. Wybrane problemy, red. R. Radek, Katowice 2013, s. 13.

${ }_{12}$ Wyrok TK z 4.05.1998 r., K 38/97, OTK 1998/3, poz. 31.

13 W. Brzozowski, Współdziałanie władz publicznych, PiP 2010/2, s. 3.

14 B. Banaszak, Prawo konstytucyjne, Warszawa 2015, s. 612. 
gminy, powiaty i województwa, co oznacza, że kwestie szczegółowe związane z omawianą problematyką pozostawiono regulacji ustawodawcy zwykłego ${ }^{15}$. Obecnie obowiązujące ustawy samorządowe przewidują współpracę jednostek samorządu terytorialnego pod postacią zawierania porozumień, zawiązywania stowarzyszeń czy tworzenia związków, którym to poświęcony jest niniejszy artykuł.

Związek międzygminny jest formą dobrowolnego ${ }^{16}$ współdziałania gmin stosowaną w celu wspólnej realizacji zadań publicznych, zwłaszcza podejmowania przedsięwzięć przekraczających możliwości jednej gminy ${ }^{17}$. Stanowi on odrębny podmiot prawa publicznego wyposażony w osobowość prawną ${ }^{18}$, czyli zdolność posiadania praw i obowiązków majątkowych oraz możność nabywania tych praw i obowiązków poprzez działania organów związku. Związek może samodzielnie występować w obrocie prawnym, dokonywać czynności cywilnoprawnych i podejmować odpowiednie czynności procesowe ${ }^{19}$. W żadnej z ustaw nie pojawia się jego definicja legalna. Ustawa o samorządzie gminnym wskazuje jedynie w art. 64 ust. 1, iż „w celu wspólnego wykonywania zadań publicznych gminy mogą tworzyć związki międzygminne”. Związek międzygminny może być powołany do życia również dla wspólnej obsługi administracyjnej, finansowej i organizacyjnej określonych podmiotów (art. 64 ust. $1 \mathrm{w}$ zw. z art. 10a u.s.g.).

Związek, o którym mowa, nie jest jednostką samorządu terytorialnego ${ }^{20}$, nie stanowi też substytutu jednostki samorządu terytorialnego wyższego stopnia ani też nie zastępuje tworzących go gmin ${ }^{21}$. Tezę taką potwierdza NSA w wyroku z 24.02.2010 r., nadmieniając, że „Związki międzygminne, chociaż tworzone są przez jednostki samo-

15 A. Skoczylas, W. Piątek [w:] Konstytucja RP, red. M. Safjan, L. Bosek, t. 2, Komentarz do art. 87-243, Warszawa 2016, s. 960.

${ }^{16}$ Wyjątek od zasady dobrowolności wprowadza art. 64 ust. 4 u.s.g.

17 Wyrok SN z 2.04.2003 r., I CK 265/02, LEX nr 81300.

18 J. Zimmermann, Prawo administracyjne, Warszawa 2014, s. 263.

19 T. Jędrzejewski [w:] Z. Bukowski, T. Jędrzejewski, P. Rączka, Ustrój samorządu terytorialnego, Toruń 2013, s. 292.

${ }^{20}$ H. Izdebski, Samorząd terytorialny. Podstawy ustroju i działalności, Warszawa 2014, s. 396.

${ }^{21}$ B. Banaszak, Prawo..., s. 613. 
rządu terytorialnego dla wspólnego wykonywania zadań publicznych, nie posiadają statusu jednostki samorządu terytorialnego. Związki międzygminne są oddzielną kategorią jednostek organizacyjnych posiadających osobowość prawną, których nie można zaliczyć ani do kategorii «gminna jednostka organizacyjna», ani do kategorii «gminna osoba prawna» - są podmiotami odrębnymi od jednostek samorządu terytorialnego" 22 .

Na temat podmiotów tworzących związek wypowiada się SA w Poznaniu w wyroku z 30.04.1992 r. ${ }^{23}$, uściślając, że „ustawowo przewidzianą wyłącznie dla gmin, formą zrzeszania się w celu wspólnego wykonywania zadań publicznych są [...] związki międzygminne”. Związek międzygminny tworzyć może również miasto na prawach powiatu, takie miasto powinno jednak w ramach związku realizować zadania gminne, a nie powiatowe ${ }^{24}$. Celem utworzenia związku jest wspólne wykonywanie zadań publicznych, czyli wszelkich spraw publicznych o znaczeniu lokalnym, służących zaspokajaniu zbiorowych potrzeb społeczności ${ }^{25}$. Aby można było mówić o „wspólnym” wykonawstwie wskazanych zadań, niezbędne jest uzgodnione przez gminy, będące uczestnikami związku, przekazanie zadań gmin na rzecz związku międzygminnego, który te zadania będzie realizował w imieniu własnym i we własnym zakresie ${ }^{26}$. Przepisy nie wprowadzają ograniczeń w zakresie liczby związków, jakie może tworzyć gmina, czy liczby związków, do jakich może przystąpiće ${ }^{27}$. Jednak orzecznictwo potwierdza, iż gmina nie może należeć do dwóch lub więcej związków międzygminnych realizujących te same zadania publiczne $^{28}$.

${ }^{22}$ Wyrok NSA z 24.02.2010 r., II FSK 1585/08, LEX nr 595838.

${ }^{23}$ Wyrok SA w Poznaniu z 30.04.1992 r., I ACr 295/92, „Wokanda” 1993/4, s. 25.

24 A. Agopszowicz, Z. Gilowska, Ustawa o gminnym samorządzie terytorialnym. Komentarz, Warszawa 1999, s. 436.

25 B. Adamiak, J. Borkowski, Instytucje prawne sądowej ochrony samodzielności gminy, ST 1991/1-2, s. 39-40.

26 E.J. Nowacka, Polski samorzad terytorialny, Warszawa 2005, s. 173-176.

27 Ustawa o samorządzie gminnym. Raport specjalny, red. B. Dolnicki, Warszawa 2016, s. 94

${ }^{28}$ Wyrok WSA w Gliwicach z 4.03.2008 r., IV SA/Gl 49/08, LEX nr 466375. 


\section{Procedura utworzenia związku międzygminnego}

Organami uprawnionymi do podjęcia uchwał o utworzeniu związku międzygminnego są rady poszczególnych gmin ${ }^{29}$. Czynią to zwykłą większością głosów w obecności co najmniej połowy ustawowego składu rady. Utworzenie związku wymaga także opracowania i ustanowienia jednobrzmiącego statutu. Do przyjęcia statutu dochodzi bezwzględną większością głosów ustawowego składu rady odpowiednio przez rady zainteresowanych gmin albo radę zainteresowanej gminy, przy czym projekt statutu - podobnie jak koncepcja utworzenia związku - podlega uzgodnieniu z wojewodą. Zajęcie stanowiska przez wojewodę następuje w terminie 30 dni od dnia doręczenia projektu statutu. W postępowaniu w sprawie skonsultowania omawianego projektu gminy zamierzające utworzyć związek reprezentuje wójt jednej z gmin upoważniony przez wójtów pozostałych gmin.

Statut związku powinien określać przede wszystkim nazwę, siedzibę związku, uczestników i czas trwania związku, a także zadania związku. Niezbędne jest, aby statut zawierał postanowienia dotyczące organów związku oraz zakresu i trybu ich działania. Innymi zagadnieniami, do których powinien się odnosić statut, są: zasady korzystania z obiektów i urządzeń związku, zasady udziału w kosztach wspólnej działalności, zyskach i pokrywania strat związku, zasady przystępowania i występowania członków, zasady likwidacji związku (art. 67 ust. 2 u.s.g.). Wyliczenie powyższych elementów kreujących statut ma charakter otwarty i przykładowy ${ }^{30}$, co pozwala na dostosowanie każdorazowo jego treści do specyfiki i potrzeb danego związku międzygminnego.

Po zakończeniu przez wszystkie rady gmin tworzące związek wyżej omówionych etapów proceduralnych, konieczne jest poinformowanie wojewody przez wójta o utworzeniu związku. Informacja taka zawiera oznaczenie uchwał rad gmin o utworzeniu związku oraz

29 B. Dolnicki, Samorząd terytorialny, Warszawa 2016, s. 333.

${ }^{30}$ R. Raszewska, Statut związku komunalnego, „Przegląd Prawa i Administracji” 1996/35, s. 35 . 
o przyjęciu jego statutu. Dołącza się do niej zarówno obie uchwały, statut, jak i wyciągi z protokołów posiedzeń rad w części dotyczącej trybu podejmowania uchwał ${ }^{31}$. Wojewoda w terminie $30 \mathrm{dni}$ od dnia otrzymania niniejszej wiadomości przekazuje zgłoszenie w sprawie rejestracji związku międzygminnego do organu prowadzącego elektroniczny rejestr związków, czyli ministra właściwego do spraw administracji publicznej ${ }^{32}$. Obecne reguły funkcjonowania rejestru określa rozporządzenie Ministra Spraw Wewnętrznych i Administracji z 22.12.2015 r. w sprawie rejestru związków międzygminnych oraz ogłaszania statutów związków i ich zmian ${ }^{33}$. Rejestr jest jawny i publikuje się go w Biuletynie Informacji Publicznej na stronie podmiotowej ministra właściwego do spraw administracji publicznej ${ }^{34}$.

Organ prowadzący rejestr, w terminie 7 dni od dnia dokonania wpisu w rejestrze, zawiadamia wójta, wojewodę oraz właściwą miejscowo regionalną izbę obrachunkową o rejestracji związku. Po czym wojewoda, w ciągu 14 dni od dnia otrzymania zawiadomienia, ogłasza statut związku w wojewódzkim dzienniku urzędowym. Dzień wydania wojewódzkiego dziennika urzędowego jest datą ogłoszenia statutu ${ }^{35}$. Czynność ogłoszenia wywiera doniosłe skutki prawne w kontekście podmiotowości i samodzielności związku międzygminnego, gdyż powoduje nabycie przez związek osobowości prawnej. Po zarejestrowaniu i z dniem ogłoszenia związek międzygminny staje się sukcesorem praw i obowiązków związanych z urzeczywistnieniem przekazanych zadań. Dzień ogłoszenia to dzień, w którym zadania gmin przekazane związkowi stają się zadaniami samego związku³ ${ }^{36}$.

${ }_{31}$ M. Ofiarska, Formy publicznoprawne współdziałania jednostek samorządu terytorialnego, Warszawa 2008, s. 470.

${ }_{32}$ M. Krawczyk, Związki i porozumienia międzygminne, „Zeszyty Naukowe UPH w Siedlcach - Seria Administracja i Zarządzanie” 2011/91, s. 173.

${ }^{33}$ Rozporządzenie Ministra Spraw Wewnętrznych i Administracji z 22.12.2015 r. w sprawie rejestru związków międzygminnych oraz ogłaszania statutów związków i ich zmian (Dz.U. poz. 2334).

${ }_{34}$ Zob. https://bip.mswia.gov.pl/bip/zwiazki-miedzygminne-zw/23826,Zwiazki-miedzygminne-zwiazki-powiatow-oraz-zwiazki-powiatowo-gminne.html (dostęp: 26.10.2018 r.).

35 B. Dolnicki, Samorząd..., s. 335.

36 S. Piątek, Ustawowe podstawy związków komunalnych, ST 1991/1-2, s. 66. 
$\mathrm{Na}$ ostatnim etapie procesu rejestracyjnego wojewoda $\mathrm{w}$ terminie 7 dni od dnia ogłoszenia statutu przekazuje do organu prowadzącego rejestr informację o ogłoszeniu statutu.

\section{Doniosłość skutków prawnych utworzenia związku międzygminnego}

Wskutek powołania do życia związku jednostek samorządu terytorialnego dochodzi do przekazania mu - przez tworzące go gminy - określonych uprawnień i obowiązków w przedmiocie realizacji zadań publicznych, które związek zaczyna wykonywać w sposób samodzielny, czyli we własnym imieniu i na własną odpowiedzialnośćc ${ }^{37}$. Zadania przekazane stają się zadaniami własnymi związku ze wszystkimi tego prawnymi implikacjami ${ }^{38}$. Oznacza to, że jednostka po przekazaniu zadań publicznych nie powinna ich wykonywać w zakresie, który pokrywałby się z kompetencją związku ${ }^{39}$. Jak akcentuje TK w wyroku z 4.05.1998 r., „z samej istoty związku komunalnego wynika ograniczenie samodzielności tworzących go gmin w takim zakresie, w jakim zadania publiczne wykonywane są przez związek. Zakres tych ograniczeń uwarunkowany jest celem, czyli wspólnym wykonywaniem zadań publicznych" ${ }^{40}$.

Żadna z ustaw nie prezentuje katalogu zadań publicznych, które mogą być wykonywane przez związek, z tego też powodu można przyjąć, iż do takich zadań zalicza się czynności realizowane w formach administracyjnoprawnych i cywilnoprawnych ${ }^{41}$. Co więcej, dopuszczalne jest przekazanie zadań w całości, jak i w części. Przekazanie częściowe wymaga jednak precyzyjności w określeniu jego zakresu dla unik-

37 B. Banaszak, Prawo..., s. 612.

${ }^{38}$ Uchwała RIO z 16.06.1995 r., XIII/86/95, OSS 1995/4, poz. 157.

39 M. Ofiarska, Formy..., s. 445.

${ }^{40}$ Wyrok TK z 4.05.1998 r., K 38/97, OTK 1998/3, poz. 31.

${ }^{41}$ A. Miruć, Współdziałanie podmiotów zajmujacych się pomoca społeczna [w:] Formy wspótdziałania jednostek samorządu terytorialnego, red. B. Dolnicki, Warszawa 2012, s. 53-54. 
nięcia w przyszłości sporów kompetencyjnych ${ }^{42}$. Zgodnie z poglądem M. Kruszewskiej-Gagoś zadania cząstkowe powinny być wskazane w statucie w taki sposób, aby zarówno organ nadzoru, jak i organ rejestrowy mogły bez problemu ustalić, który fragment zadania został przekazany na rzecz związku międzygminnego, a który pozostał w zakresie zadań gminy ${ }^{43}$.

Zadania związków mogą być ujęte w sposób ogólny i szczegółowy ${ }^{44}$. Możliwe jest

1) określenie generalnych celów, do których będzie dążył związek;

2) uściślenie przedmiotu działalności (dziedzin i rodzajów działalności);

3) wskazanie konkretnych czynności, które związek będzie podejmowa ${ }^{45}$.

Związek międzygminny posiada osobowość prawną, czyli zdolność występowania w obrocie prawnym w charakterze podmiotu praw oraz obowiązków jako strona stosunku cywilnoprawnego. Jak zaznacza J. Jezioro, osobowość prawna jest kategorią ściśle normatywną, gdyż osobowość tę posiadają tylko te podmioty, którym przepisy prawne kwalifikację taką przyznają ${ }^{46}$. W literaturze podnosi się, że osobowość prawna związku jest niejako rękojmią samodzielności prawnej działania związku ${ }^{47}$. Samodzielność wynika z faktu, że związki międzygminne wykonują zadania publiczne w imieniu własnym i na własną odpowiedzialność ${ }^{48}$. Działanie we własnym imieniu wiąże się z podejmowaniem czynności związanych z wykonywaniem zadań publicz-

${ }^{42}$ A. Marekwia [w:] Związki międzygminne. Komentarz, R. Adamus, T. Jasiński, E. Kurowska, A. Marekwia, Warszawa 2012, s. 22.

${ }^{43}$ M. Kruszewska-Gagoś, Związki międzygminne i związki powiatów w aspekcie oddziaływań nadzorczych, „Administracja. Teoria. Praktyka” 2014/1, s. 78.

${ }_{44}$ P. Karankowski, Związki komunalne i ich rozmieszczenie w układzie wojewódzkim, „Finanse Komunalne” 1996/6, s. 57.

${ }^{45}$ P. Czechowski, A. Jaroszyński, S. Piątek, Komentarz do ustawy o samorządzie terytorialnym, Warszawa 1997, s. 164.

${ }^{46}$ J. Jezioro, Osobowość prawna [w:] Mała encyklopedia prawa, red. U. Kalina-Prasznic, Warszawa 2005, s. 359.

47 A. Błaś, Funkcje osobowości prawnej gmin i związku komunalnego, „Przegląd Prawa i Administracji” 1996/35, s. 36.

48 J. Dominowska, Ustawa o samorządzie gminnym. Komentarz, Warszawa 2011, s. 631. 
nych pod nazwą związku, gdyż jak już wyżej była mowa - uprawnienia i powinności wynikające z przekazanych związkowi zadań stają się uprawnieniami i powinnościami samego związku ${ }^{49}$. Sytuację taką można uznać za odstępstwo od konstytucyjnej zasady pierwszeństwa wykonywania zadań własnych przez gminę jako jednostkę samorządu terytorialnego. Działanie na własną odpowiedzialność pociąga za sobą konieczność ponoszenia skutków swoich działań, nie tylko administracyjnych, lecz także cywilnych. Związek jako twór odrębny od tworzących go jednostek samorządowych nie może przenosić na inne podmioty odpowiedzialności za negatywne następstwa podejmowanych czynności i wykonywanych zadań ${ }^{50}$.

Związek międzygminny - jako podmiot prawa publicznego cechujący się swoistą autonomicznością - posiada własną strukturę organizacyjną. Jego organem stanowiącym i kontrolnym jest zgromadzenie związku, które w zakresie zadań zleconych związkowi wykonuje kompetencje przysługujące radzie gminy. Zgromadzenie związku posiada kompetencje wyłączne w zakresie:

1) wnioskowania do rad gmin o przyjęcie zmian w statucie;

2) wyboru i odwołania zarządu;

3) przyjmowania kierunków działań związku;

4) przyjmowania sprawozdań z działalności związku, także finansowej;

5) uchwalania programów i strategii rozwoju;

6) udzielania absolutorium zarządowi związku;

7) podejmowania uchwał w sprawach majątkowych, które przekraczają zakres zwykłego zarządu;

8) ustalania wysokości kwoty, do której zarząd ma prawo zaciągania zobowiązań;

9) uchwalania regulaminu organizacyjnego związku;

10) kontroli i nadzoru nad działalnością organu wykonawczego związku;

11) podejmowania uchwał w sprawie likwidacji związku ${ }^{51}$.

${ }^{49}$ Wyrok WSA we Wrocławiu z 7.02.2011 r., II SA/Wr 559/10, LEX nr 994086.

50 Z. Pławecki [w:] A. Szewc A., G. Jyż, Z. Pławecki, Ustawa o samorządzie gminnym. Komentarz, Warszawa 2012, s. 747.

51 B. Dolnicki, Samorząd..., s. 339. 
Zgromadzenie związku tworzą wójtowie gmin uczestniczących w związku. Ich członkostwo powstaje ex lege z momentem uzyskania przez związek międzygminny osobowości prawnej. Na wniosek wójta rada gminy może powierzyć reprezentowanie gminy w zgromadzeniu zastępcy wójta albo radnemu ${ }^{52}$. Do powierzenia dochodzi w drodze uchwały rady gminy, przy czym wyznaczenie osoby może mieć charakter indywidualny lub może polegać na trwałym wskazaniu stanowiska w organach gminy, a osoba każdorazowo je zajmująca będzie reprezentantem gminy w zgromadzeniu związku ${ }^{53}$. Nie jest również wykluczone delegowanie innych osób niewchodzących w skład organów danej gminy ${ }^{54}$. Zgromadzenie związku jest organem kolegialnym i podejmuje uchwały bezwzględną większością głosów statutowej liczby członków zgromadzenia. Statut może przewidywać kwalifikowaną większość (na przykład 2/3 głosów statutowej liczby członków zgromadzenia) przy podejmowaniu uchwał dotyczących budżetu związku bądź wniosku o zmianę statutu ${ }^{55}$. Zgodnie z art. 72 ust. 1 u.s.g. sposobem zakwestionowania uchwały jest jej zaskarżenie w formie wniesienia pisemnego sprzeciwu przez członka zgromadzenia w ciągu 7 dni od dnia jej podjęcia ${ }^{56}$. Wniesienie sprzeciwu wstrzymuje wykonanie uchwały i wymaga ponownego rozpatrzenia sprawy. Zgłoszenie sprzeciwu po raz kolejny wobec uchwały podjętej w wyniku ponownego rozpatrzenia sprawy jest niedopuszczalne ${ }^{57}$.

Organem wykonawczym związku międzygminnego jest zarząd. Za jego główne zadanie uważa się prowadzenie spraw związku i reprezentowanie go na zewnątrz. Dodatkowo zarząd związku międzygminnego: s. 130 .

${ }^{52}$ M. Gurdek, Status prawny zastępcy wójta, „Przegląd Prawa Publicznego” 2008/7-8,

${ }^{53}$ T. Jędrzejewski [w:] Z. Bukowski, T. Jędrzejewski, P. Rączka, Ustrój..., s. 293.

${ }_{54}$ M. Ofiarska, Statuty związków międzygminnych - uwarunkowania prawne a praktyka [w:] Formy..., red. B. Dolnicki, s. 313.

55 B. Dolnicki, Samorząd..., s. 337.

${ }^{56}$ Niedotrzymanie skutkuje ujemnymi konsekwencjami w postaci bezskuteczności wniesionego środka zaskarżenia - A. Marekwia [w:] Zwiq̨zki..., R. Adamus, T. Jasiński, E. Kurowska, A. Marekwia, s. 89.

${ }^{57}$ I. Skrzydło-Niżnik, Model ustroju samorządu terytorialnego w Polsce na tle zagadnień ustrojowego prawa administracyjnego, Kraków 2007, s. 538. 
1) przygotowuje projekty uchwał zgromadzenia;

2) określa sposób wykonania uchwał zgromadzenia;

3) opracowuje projekty planu finansowego;

4) składa zgromadzeniu związku sprawozdania $\mathrm{z}$ wykonania planu finansowego;

5) prowadzi rozliczenia finansowe $z$ członkami związku;

6) promuje związek i wyznacza kierunki jego rozwoju ${ }^{58}$.

Zarząd związku może być jednoosobowy albo wieloosobowy ${ }^{59}$. Powołuje go zgromadzenie związku spośród swoich członków. Przepisy u.s.g. nie regulują problematyki długości kadencji zarządu związku, zatem kwestia ta powinna zostać wskazana w statucie konkretnego związku. Jak widać na przykładach obecnie obowiązujących statutów, w praktyce najczęściej ustala się kadencję zarządu odpowiadającą kadencji zgromadzenia związku (w myśl \$ 15 statutu Związku Gmin Powiatu Tureckiego w Turku „kadencja zarządu pokrywa się $\mathrm{z}$ kadencją zgromadzenia" ${ }^{00}$ ). Inną koncepcją jest określanie kadencji w latach ${ }^{61}$ (zgodnie z $\$ 18$ statutu Związku Międzygminnego „Czysty Region” z siedzibą w Kędzierzynie-Koźlu „zarząd składa się z przewodniczącego zarządu oraz dwóch członków zarządu wybieranych przez zgromadzenie na okres kadencji trwającej 4 lata" ${ }^{2}$ ).

Zarząd związku jest organem kolegialnym. Wydaje decyzje w formie uchwał podjętych bezwzględną większością głosów statutowej liczby swoich członków. Oświadczenia woli w imieniu związku w ramach

${ }^{58}$ R. Adamus [w:] Związki..., R. Adamus, T. Jasiński, E. Kurowska, A. Marekwia, s. 106.

${ }^{59}$ O ile statut tak stanowi, dopuszczalny jest wybór członków zarządu spoza członków zgromadzenia w liczbie nieprzekraczającej 1/3 składu zarządu związku M. Ofiarska, Formy..., s. 491.

${ }^{60}$ Statut Związku Gmin Powiatu Tureckiego w Turku z 24.11.2008 r., http://bip. gmina.turek.pl/biuletyn-informacji-publicznej/prawo-lokalne/uchwaly-rady-gminy/ kadencja-2006-2010/2008/uchwala-nr-xxii13208-rady-gminy-turek-z-dnia-24-listopada2008-r.-w-sprawie-przyjecia-statutu-zwiazku-miedzygminnego-zwiazek-gmin-powiatutureckiego.html (dostęp: 26.10.2018 r.).

${ }^{61}$ R. Adamus [w:] Związki..., R. Adamus, T. Jasiński, E. Kurowska, A. Marekwia, s. 105.

${ }^{62}$ Statut Związku Międzygminnego „Czysty Region” z siedzibą w Kędzierzynie-Koźlu z 14.07.2008 r., http://www.czystyregion.bip-e.pl/cr/statut/5903,Statut-ZwiazkuMiedzygminnego-quotCzysty-Regionquot.html (dostęp: 26.10.2018 r.). 
zwykłego zarządu mieniem składają dwaj członkowie zarządu lub jeden członek zarządu i osoba upoważniona przez zarząd (pełnomocnik). Zarząd posiada uprawnienie do udzielania przewodniczącemu upoważnienia do składania jednoosobowo oświadczeń woli związanych z prowadzeniem bieżącej działalności związku ${ }^{63}$.

\section{Samodzielność finansowa związków międzygminnych}

Samodzielność związków międzygminnych jest zjawiskiem niezwykle złożonym, dotyczącym różnorodnych aspektów jego działania, także tych ekonomicznych i finansowych. W myśl art. 73a ust. 1 u.s.g. „do gospodarki finansowej związku międzygminnego stosuje się odpowiednio przepisy o gospodarce finansowej gmin”. Regulację o niniejszej treści potwierdza art. 4 ust. 2 ustawy z 27.08.2009 r. o finansach publicznych ${ }^{64}$, zgodnie z którym przepisy dotyczące jednostek samorządu terytorialnego stosuje się odpowiednio do związków jednostek samorządu terytorialnego ${ }^{65}$.

W oparciu o powyższe można rzec, że związki międzygminne prowadzą gospodarkę finansową na podstawie takich samych regulacji co gminy, z tym jednakże zastrzeżeniem, że związek nie uchwala budżetu, lecz przyjmuje plan finansowy (art. 73a ust. 2 u.s.g.) ${ }^{66}$. Plan finansowy uchwalany jest przez zgromadzenie związku ${ }^{67}$. Natomiast odpowiedzialność za przygotowanie i przedstawienie jego projektu zgromadzeniu związku spoczywa na zarządzie związku ${ }^{68}$. Projekt

63 B. Dolnicki, Samorząd..., s. 340.

${ }^{64}$ Ustawa z 27.08.2009 r. o finansach publicznych (Dz.U. z 2017 r. poz. 2077 ze zm.).

${ }^{65}$ Związki międzygminne, podobnie jak jednostki samorządu terytorialnego, zaliczane są do sektora finansów publicznych - L. Lipiec-Warzecha, Ustawa o finansach publicznych. Komentarz, Warszawa 2011, s. 86.

66 Z. Pławecki [w:] A. Szewc G. Jyż, Z. Pławecki, Ustawa..., s. 759.

67 Zgromadzenie związku posiada wyłączną kompetencję nie tylko do uchwalania planu finansowego, ale także do dokonywania jego zmiany w trakcie roku budżetowego - wyrok WSA we Wrocławiu z 10.02.2004 r., I SA/Wr 2544/03, ZNSA 2005/1, poz. 88.

${ }_{68}$ J. Kastelik, Gospodarka finansowa związku komunalnego, „Administracja. Teoria. Dydaktyka. Praktyka” 2007/2(7), s. 128. 
planu finansowego powinien odpowiadać warunkom, jakie ustawa stawia budżetowi gminy. Oznacza to, że niezbędne jest objęcie projektem wszystkich zadań, które będą podejmowane przez dany związek $^{69}$. Zarząd związku przedkłada projekt zgromadzeniu związku oraz regionalnej izbie obrachunkowej - do zaopiniowania - do 15 listopada poprzedniego roku budżetowego. Warto zasygnalizować, że bez zgody zarządu zgromadzenie nie może wprowadzić w projekcie zmian powodujących zwiększenie wydatków nieznajdujących pokrycia w planowanych dochodach lub zwiększenie planowanych dochodów bez jednoczesnego wskazania, z jakich źródeł będą one pochodzić ${ }^{70}$.

Plan finansowy uchwala zgromadzenie związku na okres roku kalendarzowego, jednakże czyni to jeszcze przed rozpoczęciem roku budżetowego, nie później niż do 31 stycznia tego roku. W przypadku nieuchwalenia planu do 1 stycznia roku budżetowego, podstawą gospodarki finansowej związku staje się projekt przedstawiony przez zarząd związku. Jeśli zgromadzenie nie podejmie uchwały do końca marca, to plan finansowy dla związku ustala właściwa regionalna izba obrachunkowa ${ }^{71}$. Przyjęcie planu finansowego przez zgromadzenie związku w okresie, kiedy ta kompetencja przeszła już na regionalną izbę obrachunkową, nie może wywołać żadnych skutków prawnych dla związku. Uchwała zgromadzenia związku podjęta po terminie 31 marca jest nieważna ${ }^{72}$.

Wykonanie omawianego planu należy do zadań zarządu związku. Przy realizacji planu jest on upoważniony do dokonywania w nim zmian i dysponowania rezerwami. Na zarządzie spoczywa także obowiązek ogłoszenia uchwały w sprawie planu finansowego i w późniejszej kolejności ogłoszenia sprawozdania z jego wykonania.

Do głównych dochodów związku międzygminnego zalicza się dochody pochodzące $z$ budżetów poszczególnych gmin, przeznaczone

\footnotetext{
69 Z. Pławecki [w:] A. Szewc G. Jyż, Z. Pławecki, Ustawa..., s. 760.

${ }^{70}$ J. Glumińska-Pawlic [w:] Ustawa o samorządzie gminnym. Komentarz, red. B. Dolnicki, Warszawa 2016, s. 1091.

${ }^{71}$ Wyrok NSA z 4.11.1993 r., SA/Gd 1373/93, ONSA 1994/4, poz. 154.

${ }^{72}$ J. Kastelik, Gospodarka..., s. 143-145.
} 
na urzeczywistnianie przekazanych zadań publicznych. Związek międzygminny czerpie dochody z majątku związku, wpływów z własnej działalności, składek i innych świadczeń członków związku uchwalonych przez zgromadzenie ${ }^{73}$. Może on otrzymywać z budżetu państwa dotacje związane z realizacją zadań zleconych przez administrację rządową, a także darowizny i zapisy osób trzecich ${ }^{74}$. Kontrolę gospodarki finansowej związków międzygminnych sprawują regionalne izby obrachunkowe ${ }^{75}$. Szczegółowe zasady prowadzenia gospodarki finansowej związków określają ich statuty.

\section{Podsumowanie}

Pojawienie się w polskim porządku prawnym modelu zdecentralizowanej władzy publicznej doprowadziło do istotnych zmian w strukturze i funkcjonowaniu administracji. Tendencje rozwojowe we współczesnym świecie ukazują, iż decentralizacja - jako zjawisko niezwykle złożone i wieloaspektowe - obecnie przybiera różnorodne formy. Jej najistotniejszym, lecz nie jedynym, przejawem jest istnienie samorządu terytorialnego. Jak trafnie podkreślono w wyroku TK z 18.02.2003 r., decentralizacja jednak „nie wyklucza [...] takich rozwiązań ustrojowych w dziedzinie samorządu terytorialnego, które polegają na wyłączeniu pewnych spraw z kompetencji organów lokalnych i przekazaniu ich innym organom władzy"76. Dodatkowo „decentralizacja władzy państwowej nie może być pojmowana jednopodmiotowo, dotyczy nie tylko samorządu terytorialnego, obejmuje znacznie szerszy katalog organów, które wskutek zaimplementowania zasady decentralizacji otrzymały przymioty władztwa publicznego"77. Owe przymioty władztwa otrzymały niewątpliwie związki międzygminne cechujące się samodzielnością w działaniu. Zgodnie z poglądem Sądu Najwyższego, związek międzygminny jest organizacją gmin umożliwiającą im połączenie sił w celu łatwiejszego i o większej

\footnotetext{
${ }^{73}$ M. Ofiarska, Formy..., s. 514.

74 B. Dolnicki, Samorząd..., s. 341.

75 Wyrok NSA z 5.10 .1994 r., SA/Kr 2904/93, „Wokanda” 1995/2, s. 35.

76 Wyrok TK z 18.02.2003 r., K 24/02, OTK-A 2003/2, poz. 11.

77 Wyrok TK z 7.01.2004 r., K 14/03, OTK-A 2004/1, poz. 1.
} 
skali zaspokajania zbiorowych potrzeb wspólnot gminnych. Związek - z woli zrzeszonych w nim gmin - wyręcza je w realizacji powierzonych mu zadań. Jego pozycja, oceniana pod kątem przedmiotu działalności, nie jest więc odmienna od pozycji zrzeszonych gmin ${ }^{78}$.

Jak wykazały powyższe rozważania, związek międzygminny posiada określoną ustawą i statutem podmiotowość administracyjnoprawną oraz osobowość prawną. Wykonuje przy użyciu władztwa administracyjnego, w swoim imieniu i na swoją rzecz, zadania publiczne tworzących go gmin ${ }^{79}$. Za niezależną pozycją związku przemawia kilka argumentów zaprezentowanych w niniejszym opracowaniu. Po pierwsze, związek międzygminny, jako podmiot wyodrębniony pod względem organizacyjnym i prawnym, podejmuje działania w formie władczej w zakresie prawa administracyjnego ${ }^{80}$, czyniąc to we własnym imieniu i na własną odpowiedzialność. Po drugie, związek posiada ustawowo określoną strukturę organizacyjną, a o zasadach jego funkcjonowania stanowi statut, będący według wielu przedstawicieli doktryny wyrazem swego rodzaju autonomii w zakresie regulacji życia wewnętrznego ${ }^{81}$. Ogłoszenie owego statutu powoduje, iż związek międzygminny staje się następcą praw i obowiązków związanych z realizacją przekazanych zadań. Gminy zaś - jako podstawowe jednostki samorządu terytorialnego - tracą prawo do wykonywania zadań publicznych w takim zakresie, w jakim wykonuje je związek ${ }^{82}$. I w końcu po trzecie, związek poszczególnych gmin prowadzi samodzielną gospodarkę finansową na podstawie przyjętego planu finansowego. Może być podmiotem dysponującym mieniem komunalnym, może je również powiększać w wyniku prowadzonej działalności ${ }^{83}$.

${ }_{78}$ Wyrok SN z 6.05.2011 r., II CSK 409/10, LEX nr 863960.

79 I. Skrzydło-Niżnik, Model..., s. 537.

${ }^{80} \mathrm{Na}$ temat podmiotowości prawnej wypowiada się m.in. A. Wiktorowska, Prawne determinanty samodzielności gminy. Zagadnienia administracyjnoprawne, Warszawa 2002, s. 58 i n.

81 B. Adamiak, Statut gminy, ST 1993/5, s. 62 i n.; R. Raszewska-Skałecka, Statut i regulamin zakładu administracyjnego jako źródło prawa, Wrocław 2007, s. 76.

${ }^{82}$ H. Izdebski, Samorząd..., s. 397.

83 E.J. Nowacka, Samorzad terytorialny $w$ administracji publicznej, Warszawa 1997, s. 119. 


\section{Bibliografia:}

Adamiak B., Statut gminy, ST 1993/5

Adamiak B., Borkowski J., Instytucje prawne sądowej ochrony samodzielności gminy, ST 1991/1-2

Agopszowicz A., Gilowska Z., Ustawa o gminnym samorządzie terytorialnym. Komentarz, Warszawa 1999

Banaszak B., Konstytucja Rzeczypospolitej Polskiej. Komentarz, Warszawa 2012

Banaszak B., Prawo konstytucyjne, Warszawa 2015

Błaś A., Funkcje osobowości prawnej gmin i związku komunalnego, „Przegląd Prawa i Administracji” 1996/35

Bukowski Z., Jędrzejewski T., Rączka P., Ustrój samorządu terytorialnego, Toruń 2013

Brzozowski W., Współdziałanie władz publicznych, PiP 2010/2

Czechowski P., Jaroszyński A., Piątek S., Komentarz do ustawy o samorządzie terytorialnym, Warszawa 1997

Dąbek D., Zimmermann J., Decentralizacja poprzez samorząd terytorialny w ustawodawstwie i orzecznictwie pokonstytucyjnym [w:] Samorzad terytorialny. Zasady ustrojowe i praktyka, red. P. Sarnecki, Warszawa 2005

Dolnicki B., Samorząd terytorialny, Warszawa 2016

Dominowska J., Ustawa o samorządzie gminnym. Komentarz, Warszawa 2011

Fundowicz S., Decentralizacja władzy publicznej [w:] Encyklopedia samorzadu terytorialnego, red. K. Miaskowska-Daszkiewicz, B. Szmulik, Warszawa 2010

Giejłaszewska G., Wpływ decentralizacji na organizację terytorialna państwa [w:] Decentralizacja współczesnego państwa. Wybrane problemy, red. R. Radek, Katowice 2013

Gurdek M., Status prawny zastępcy wójta, „Przegląd Prawa Publicznego” 2008/7-8

Izdebski H., Samorząd terytorialny. Podstawy ustroju i działalności, Warszawa 2014

Jezioro J., Osobowość prawna [w:] Mała encyklopedia prawa, red. U. Kalina-Prasznic, Warszawa 2005

Karankowski P., Związki komunalne i ich rozmieszczenie w układzie wojewódzkim, „Finanse Komunalne” 1996/6

Kastelik J., Gospodarka finansowa związku komunalnego, „Administracja. Teoria. Dydaktyka. Praktyka” 2007/2(7)

Konstytucja RP, red..M. Safjan, L. Bosek, t. 2, Komentarz do art. 87-243, Warszawa 2016 
Krawczyk M., Związki i porozumienia międzygminne, "Zeszyty Naukowe UPH w Siedlcach - Seria Administracja i Zarządzanie” 2011/91

Kruszewska-Gagoś M., Związki międzygminne izwiązki powiatów w aspekcie oddziaływań nadzorczych, „Administracja. Teoria. Dydaktyka. Praktyka” 2014/1

Lipiec-Warzecha L., Ustawa o finansach publicznych. Komentarz, Warszawa 2011 Łokucijewski K., Decentralizacja, centralizacja [w:] Leksykon prawa administracyjnego. 100 podstawowych pojęć, red. E. Bojanowski, K. Żukowski, Warszawa 2009

Miruć A., Współdziałanie podmiotów zajmujących się pomoca społeczną [w:] Formy współdziałania jednostek samorządu terytorialnego, red. B. Dolnicki, Warszawa 2012

Nowacka E.J., Polski samorząd terytorialny, Warszawa 2005

Nowacka E.J., Samorząd terytorialny w administracji publicznej, Warszawa 1997

Ochendowski E., Prawo administracyjne. Część ogólna, Toruń 2006

Ofiarska M., Formy publicznoprawne współdziałania jednostek samorządu terytorialnego, Warszawa 2008

Ofiarska M., Statuty związków międzygminnych - uwarunkowania prawne a praktyka [w:] Formy współdziałania jednostek samorządu terytorialnego, red. B. Dolnicki, Warszawa 2012

Piątek S., Ustawowe podstawy związków komunalnych, ST 1991/1-2

Raszewska-Skałecka R., Statut i regulamin zakładu administracyjnego jako źródło prawa, Wrocław 2007

Raszewska R., Statut związku komunalnego, „Przegląd Prawa i Administracji” $1996 / 35$

Skrzydło-Niżnik I., Model ustroju samorządu terytorialnego w Polsce na tle zagadnień ustrojowego prawa administracyjnego, Kraków 2007

Stępień J., Samorząd w ustawie zasadniczej, ST 1994/11

Szewc A., Jyż G., Pławecki Z., Ustawa o samorządzie gminnym. Komentarz, Warszawa 2012

Ustawa o samorzadzie gminnym. Komentarz, red. B. Dolnicki, Warszawa 2016

Ustawa o samorządzie gminnym. Raport specjalny, red. B. Dolnicki, Warszawa 2016

Wiktorowska A., Prawne determinanty samodzielności gminy. Zagadnienia administracyjnoprawne, Warszawa 2002

Zimmermann J., Prawo administracyjne, Warszawa 2014

Związki międzygminne. Komentarz, R. Adamus, T. Jasiński, E. Kurowska, A. Marekwia, Warszawa 2012 